\title{
KARAKTERISTIK PENDERITA TUBERKULOSIS TAHUN 2011-2012 DI PUSKESMAS HARAPAN RAYA PEKANBARU
}

\author{
Tri Siwi KN, Wiwik Norlita, Novita R \\ Fakultas MIPA dan Kesehatan Universitas Muhammadiyah Riau
}

Email: trisiwiningrum@yahoo.com

\begin{abstract}
ABSTRAK
Penderita Tubekulosis pada saat ini sangat banyak terjadi pada usia dewasa khususnya pada usia 2145 tahun. Penderita tuberkulosis di Asia Tenggara dilaporkan sebanyak 35 persen. Tuberkulosis merupakan penyakit infeksi kronis yang disebabkan oleh Myobacterium tuberculosis,yang dapat ditularkan melalui percikan dahak (droplet) dari penderita TBC kepada individu lain yang rentan. Tujuan Penelitian ini adalah untuk melihat karakteristik Penderita Tuberkulosis Di Puskesmas Harapan Raya Tahun 2011-2012 Pekanbaru. Jenis Penelitian yang digunakan adalah metode deskriptif dengan teknik pengambilan sampel total sampling berdasarkan ciri atau sifat-sifat populasi yang sudah diketahui sebelumnya dengan jumlah 60 sampel. Teknik pengumpulan data adalah lembaran Check List dan analisa data yang digunakan adalah univariate. Hasil penelitian secara umum yaitu karakteristik penderita tuberkulosis di Puskesmas Harapan Raya tahun 2011-2012 Pekanbaru menunjukan bahwa karakteristik penderita tuberkulosis berdasarkan usia tahun 2011-2012 adalah mayoritas berada pada usia dewasa (21-45 tahun) sebanyak 34 responden $(56,67 \%)$. Berdasarkan jenis kelamin tahun 2011-2012 adalah mayoritas laki-laki sebanyak 44 responden $(73,33 \%)$. Berdasarkan hasil pemeriksaan BTA mayoritas adalah positif $3+$ sebanyak 22 responden $(36,67 \%)$.
\end{abstract}

Kata kunci: Karakteristik, Penderita Tuberkulosis

\section{PENDAHULUAN}

Tuberkulosis merupakan penyakit gangguan pernapasan yang disebabkan oleh bakteri tuberkulosis yang mengakibatkan paruparu mengalami infeksi (Mujiatun, 2009).

Gejala penyakit tuberkulosis ditandai dengan batuk yang lebih dari 2 minggu dan batuknya tesebut kadang bercampur darah (Admin, 2012). Selain itu yang menjadi karakteristik penderita TBC antara lain usia, yang mayoritas pada balita dan lansia, pekerjaan yang terpapar dengan sumber polusi, ventilasi rumah yang tidak memenuhi standar kesehatan, jenis kelamin, faktor sosial ekonomi dan hasil pemeriksaan BTA yang biasanya ditemukan hasil uji positif pada penderita TBC. Jika faktor-faktor tersebut diabaikan, penderita TBC dapat mengalami berbagai komplikasi yang bisa mengakibatkan kematian (Sarwadji, 2001 \& Setiowati, 2007).

WHO pada tahun 1992 sudah mencanangkan penyakit tuberkulosis sebagai penyakit yang masuk dalam daftar Global Emergency. Penyakit infeksi ini pun diperkirakan telah merenggut nyawa 1,8 juta jiwa di seluruh dunia pada tahun 2000. Laporan Badan Kesehatan Dunia (WHO) tahun 2001 mengungkapkan terdapat sekitar 3,8 juta kasus baru TBC di seluruh dunia, dan 90 persen diantaranya berada di negara berkembang. Sedangkan pada tahun 2004, WHO melaporkan bahwa ada 8,8 juta kasus penyakit TBC yang baru pada tahun 2002 (Perhimpunan Dokter Paru Indonesia, 2006).

Dalam distribusi beban TBC secara global, pada tahun 2003 wilayah Asia Tenggara menyumbang kasus TBC sebesar 35 persen, wilayah Afrika sebesar 22 persen, dan Pasifik Timur sebesar 22 persen. Dua puluh dua negara dengan beban TBC tinggi menyumbang 80 persen dari penambahan kasus baru setiap tahunnya, dengan India dan Cina sebagai penyumbang sebanyak 35 persen. Indonesia kini menempati urutan ketiga penderita 
penyakit TBC terbanyak di dunia, setelah Cina dan India. Di perkirakan terdapat 582.000 kasus baru TBC pertahun di Indonesia, yang hampir separuhnya adalah TBC paru dengan hasil pemeriksaan BTA positif (Wahyu, 2008).

Menurut Ditjen PP\&PL Kementrian Kesehatan RI 2011, data laporan situasi perkembangan TBC di Indonesia, total seluruh kasus TB tahun 2009 sebanyak 294.731 kasus, dimana 57,4 persen adalah kasus TB BTA baru Basil Tahan Asam (BTA) positif, 36,8 persen adalah kasus TB BTA negative, 3,8 persen adalah kasus TB Ekstra Paru 1,3 persen adalah kasus TB kambuh, dan 0,7 persen adalah kasus pengobatan ulang diluar kasus kambuh. Laporan Global Tuberculosis Control tahun 2011 menyebutkan bahwa India, Cina, South Afrika dan Indonesia berada pada urutan ke-4 dengan jumlah pasien TB sebesar 450 ribu kasus.

Menurut Survei Kesehatan Rumah Tangga (SKRT) tahun 1985 dan Survei Kesehatan Nasional (Suksesnas) tahun 2001, penyakit TBC merupakan penyebab kematian ketiga di Indonesia, setelah penyakit jantung dan pembuluh darah (Kardiovaskuler), dan penyakit infeksi saluran pernafasan pada semua kelompok usia. Sedangkan, dari golongan penyakit infeksi, TBC merupakan penyebab kematian utama (Wahyu, 2008).

Program pemberantasan TBC mulai diperkenalkan pada tahun 1952 di Amerika yaitu dengan menggunakan obat antituberkulosis, sehingga angka kasus TB yang dilaporkan di Amerika Serikat menurun rata-rata 6 persen setiap tahun antara 1953 dan 1985 (Smeltzer dan Brenda, 2002).

Sedangkan sejak tahun 1995, pemerintah Indonesia memprogramkan pemberantasan $\mathrm{TB}$ dengan strategi DOTS (directly observed treatment shortcourse). Meliputi komitmen pemerintah untuk mempertahankan kontrol terhadap TB, deteksi kasus TB di antara orangorang yang memiliki gejala-gejala melalui pemeriksaan dahak, pengobatan teratur selama 6-8 bulan yang diawasi, ketersediaan obat TB yang rutin dan tidak terputus, dan sistem laporan untuk monitoring dan evaluasi perkembangan pengobatan dan program dengan mekanisme pendataan yang mengacu ke arah faktor-faktor penyebab terjadinya penyakit TBC (Effendi, 2012).

Faktor-faktor yang mempengaruhi terjadinya penyakit TBC atau karakteristik yang ada pada penderita TBC sangat perlu diperhatikan sebagai salah satu indikator evaluasi dan monitoring keberhasilan program pemberantasan penyakit TBC, yaitu dengan cara mengevaluasi perkembangan karakteristik setelah diberikan pengobatan TBC sehingga program pemberantasan penyakit TBC yang dilaksanakan pemerintah berhasil secara maksimal.

Berdasarkan data Medical Record Dinas Kesehatan Kota Pekanbaru yang di peroleh peneliti pada tanggal 3 Desember 2012 menunjukkan bahwa angka penderita penyakit tuberkulosis yang tertinggi di wilayah kerja Puskesmas Pekanbaru adalah Puskesmas Harapan Raya. Data tersebut menunjukkan terjadinya penurunan angka prevalensi yang bervariasi yaitu di dapati data bahwa tahun 2009 sebesar 71 persen, tahun 2010 sebesar 69 persen, tahun 2011 sebesar 61 persen, dan tahun 2012 sebesar 31 persen yang pernah mengalami penyakit tuberkulosis.

Berdasarkan hal tersebut maka peneliti tertarik untuk melakukan penelitian yang berjudul "Karakteristik Penderita Tuberkulosis Tahun 2011-2012 Di Puskesmas Harapan Raya Pekanbaru".

\section{METODOLOGI PENELITIAN}

Dalam penelitian ini peneliti mengguankan jenis penelitian deskriptif. Menurut Notoatmodjo (2010), deskriptif yaitu dilakukan terhadap sekumpulan objek yang biasanya bertujuan untuk melihat gambaran fenomena (termasuk kesehatan) yang terjadi di dalam suatu populasi tertentu. Dalam penelitian ini peneliti ingin mengemukakan karakteristik penderita tuberkulosis berdasarkan usia, jenis kelamin, pekerjaan, hasil pemeriksaan BTA, dan Status Sosial Ekonomi. 
Dalam analisa peneliti menggunakan analisa univariate yaitu analisa yang digabungkan untuk melihat menggambarkan frekuensi dan persentase menurut Hasan (2004), dengan melihat persentase data yang terkumpul disajikan dalam bentuk tabel frekuensi dan tiap variabel dengan rumus:

$$
P=F \times 100 \%
$$

Keterangan:

P: Persentase

F: Frekuensi karakteristik penderita TBC berdasarkan usia, jenis kelamin dan hasil pemeriksaan BTA

$\mathrm{N}$ : Jumlah penderita TBC

\section{Defenisi Karakteristik}

Karakter merupakan Sifat-sifat kejiwaan, akhlak atau budi pekerti yang membedakan seseorang dari yang lain (Departemen Pendidikan dan Kebudayaan, 2002).

Karakteristik adalah ciri khas seseorang dalam meyakini, bertindak ataupun merasakan (Richard, 2009).

\section{Faktor Usia}

Beberapa faktor resiko penularan penyakit tuberkulosis di Amerika selain faktor jenis kelamin, ras, asal negara, salah satunya adalah faktor usia. Insiden tertinggi tuberkulosis paru biasanya mengenai usia dewasa muda. Di Indonesia diperkirakan $75 \%$ penderita TB Paru adalah kelompok usia produktif yaitu 15-50 tahun (Achmadi, 2005). Sedangkan menurut Smeltzer dan Bare brenda (2002), anak-anak dibawah usia 15 tahun dan dewasa antara yang berusia 15 sampai 35 tahun).

Menurut Depkes RI (2009), penggolongan usia terdiri dari masa balita ( $0-5$ tahun), masa kanak-kanak ( $>5-12$ tahun), masa remaja awal (13-17 tahun), masa remaja akhir (17-20 tahun), masa dewasa awal (2135 tahun), masa dewasa akhir (36-45 tahun), masa

lansia awal (46-55 tahun), masa lansia akhir (56-64 tahun), dan masa manula (65sampai atas) (Hardiwinoto, 2011).

\section{Faktor Jenis Kelamin}

Jenis kelamin adalah suatu konsep yang digunakan untuk mengidentifikasikan perbedaan pria dan wanita yang dilihat dari anatomi atau biologis (Ida, 2007).

Di benua Afrika banyak tuberkulosis terutama menyerang laki-laki. Pada tahun 1996 jumlah penderita TB Paru laki-laki hampir dua kali lipat dibandingkan jumlah penderita TB Paru pada wanita, yaitu 42,3 persen pada lakilaki dan 28,9 persen pada wanita. Antara tahun 1985-1987 penderita TB paru laki-laki cenderung meningkat sebanyak 2,5 persen, sedangkan penderita TB Paru pada wanita menurun 0,7 persen. TB paru Iebih banyak terjadi pada laki-laki dibandingkan dengan wanita karena laki-laki sebagian besar mempunyai kebiasaan merokok sehingga memudahkan terjangkitnya TB paru (Achmadi, 2005).

\section{Pekerjaan}

Jenis pekerjaan menentukan faktor risiko apa yang harus dihadapi setiap individu. Bila pekerja bekerja di lingkungan yang berdebu, paparan partikel debu di daerah terpapar akan mempengaruhi terjadinya gangguan pada saluran pernafasan. Paparan kronis udara yang tercemar dapat meningkatkan morbiditas, terutama terjadinya gejala penyakit saluran pernafasan dan umumnya TB Paru. Jenis pekerjaan seseorang juga mempengaruhi terhadap pendapatan keluarga yang akan mempunyai dampak terhadap pola hidup sehari-hari diantara konsumsi makanan, pemeliharaan kesehatan selain itu juga akan mempengaruhi terhadap kepemilikan rumah (kontruksi rumah).

\section{Pemeriksaan Hasil BTA (basil tahan asam)}

Pembacaan hasil pemeriksaan sediaan dahak dilakukan dengan menggunakan skala International Union Against Tuberculosis (IUAT). Pemeriksaan sputum untuk Basil Tahan Asam biasanya dilakukan pemeriksaan terhadap sputum sewaktu, sputum pagi dan sputum sewaktu (SPS). Hasil yang positif 
ditandai dengan sekurang - kurangnya 2 dari 3 spesimen sputum sewaktu, pagi, sewaktu adalah positif ditemukannya Basil Tahan Asam (BTA).Pemeriksaan mikrokopis BTA ini digunakan untuk menbantu diagnosis penyakit tuberculosis. Penulisan gradasi hasil bacaan penting, untuk menunjuk keparahan penyakit dan tingkat penularan penderita menurut Departemen Kesehatan RI, (2001) yaitu:

1. 1-9 BTA dalam 100 lapang pandang, ditulis jumlah kuman yang ditemukan.

2. 10-99 BTA dalam 100 lapang pandang disebut + atau (1+).

3. 1-10 BTA dalam 1 lapang pandang, disebut ++ atau $(2+)$.

4. > 10 BTA dalam 1 lapang pandang, disebut +++ atau (3+) (Faud, 2011).

\section{Status Sosial Ekonomi}

Keadaan sosial ekonomi berkaitan erat dengan pendidikan, keadaan sanitasi lingkungan, gizi dan akses terhadap pelayanan kesehatan. Apabila status gizi buruk maka akan menyebabkan kekebalan tubuh menurun sehingga memudahkan terkena infeksi TB paru (Chaesarani, 2013)

WHO tahun 2007 menyebutkan 90 persen penderita TB di dunia menyerang kelompok sosial ekonomi lemah atau miskin dan menurut Enarson TB merupakan penyakit terbanyak yang menyerang negara dengan penduduk berpenghasilan rendah. Sosial ekonomi yang rendah akan menyebabkan kondisi kepadatan hunian yang tinggi dan buruknya lingkungan, selain itu masalah kurang gizi dan rendahnya kemampuan untuk mendapatkan pelayanan kesehatan yang layak juga menjadi problem bagi golongan sosial ekonomi rendah (Gilarso, 2004).

\section{Pengertian Tuberkulosis}

Tuberkulosis adalah penyakit gangguan pernapasan yang disebabkan oleh bakteri tuberkulosis. Penyakit ini disebut juga TBC (tuberculosis) (Mujiatun, 2009).

TBC adalah penyakit infeksi kronis yang disebabkan oleh Myobacterium tuberculosis, sejenis bakteri berbentuk batang yang tahan asam (BTA) dengan ukuran panjang 1-4/Um dan ketebalan 0,3-0,6/Um, yang ditularkan melalui percikan dahak (droplet) dari penderita TBC kepada individu lain yang rentan (Wahyu, 2008).

\section{Penularan}

Tuberkulosis ditularkan dari orang ke orang oleh transmisi melalui udara. Individu terinfeksi, melalui berbicara, batuk, bersin, tertawa, atau bernyanyi, melepaskan droplet besar dan kecil. Droplet yang besar menetap, sementara droplet yang kecil tertahan diudara dan terhirup oleh individu yang rentan (Smeltzer dan Brenda, 2002).

Penyakit ini mudah menular, yaitu melalui udara yang dihembuskan oleh penderita pada saat bernapas atau batuk serta lendir atau dahak (Mujiatun, 2009).

Berdasarkan hasil pengamatan pada penelitian Helper Manalu dkk, penderita TB paru mempunyai kebiasaan sering tidak menutup mulut saat batuk, hal ini tentunya dapat membuat penularan TB pada orangorang yang sehat di sekitarnya. Sedangkan Menurut Tjandra Yoga (2007), TB juga mudah menular pada mereka yang tinggal di perumahan padat, kurang sinar matahari dan sirkulasi udaranya buruk/pengap, namun jika ada cukup cahaya dan sirkulasi, maka kuman TB hanya bisa bertahan selama 1-2 jam (Manalu, 2010).

\section{Tanda dan Gejala}

Keluhan yang terbanyak adalah:

1) Berat badan turun tanpa sebab yang jelas atau tidak naik dalam 1 bulan dengan penangan gizi

2) Anoreksia dengan gagal tumbuh dan berat badan tidak naik secara adekuat (failure to thrive)

3) Demam lama dan berulang tanpa sebab yang jelas, kadang-kadang panas badan mencapai 40-41 derajat celcius (bukan tifus, malaria, atau infeksi saluran pernapasan akut), dapat disertai keringat malam 
4) Batuk lama lebih dari 30 hari (Mansjoer, 2000).

\section{Penatalaksanaan Medis}

Tuberkulosis paru diobati terutama dengan agens kemoterapi (agnes antituberkulosis) selama periode 6 sampai 12 bulan. Lima medikasi garis depan digunakan: isoniasid (INH), rifampin (RIF), streptomisin (SM), etambutol (EMB), dan pirasinamid (PZA) (Smeltzer dan Brenda, 2002).

Menurut Mansjoer (2000), regimen dasar pengobatan TB adalah kombinasi INH dan RIF selama 6 bulan dengan PZA pada 2 bulan pertama. Pada TB berat dan ekstrapulmonal biasanya pengobatan dimulai dengan kombinasi 4-5 obat selama 2 bulan (ditambah EMB dan streptomisin, dilanjutkan dengan INH dan RIF selama 4-10 bulan sesuai perkembangan klinis.

\section{HASIL DAN PEMBAHASAN}

Berdasarkan hasil penelitian yang telah dilakukan peneliti tentang "Karakteristik Penderita Tuberkulosis di Puskesmas Harapan Raya Tahun 2011-2012 Pekanbaru". Di ruang Medical Record (MR) pada tanggal 27 Juli s/d 1 Agustus 2013, pada data sekunder penderita Tuberkulosis tahun 20112012 adalah sebagai berikut:

Tabel. 1. Distribusi Frekuensi Usia Penderita Tuberkulosis Tahun 2011-2012 Di Puskesmas Harapan Raya Pekanbaru

\begin{tabular}{|c|c|c|c|c|c|c|c|}
\hline \multirow{2}{*}{ No } & \multirow{2}{*}{ Usia } & \multicolumn{2}{|r|}{2011} & \multicolumn{2}{|c|}{2012} & \multicolumn{2}{|c|}{ Total } \\
\hline & & $\mathbf{f}$ & $\%$ & $\mathbf{f}$ & $\%$ & $\mathbf{f}$ & $\%$ \\
\hline 1. & Balita (0-5 tahun) & - & - & - & - & - & - \\
\hline 2. & Kanak-kanak ( $>5-12$ tahun) & - & - & 1 & 3,23 & 1 & 1,67 \\
\hline 3. & Remaja (13-20 tahun) & & & & & ) & \\
\hline 4. & Dewasa (21-45 tahun) & 4 & 13,79 & 1 & 3,23 & 5 & 8,33 \\
\hline 5. & Lansia (46-64 tahun) & 14 & 48,28 & 20 & 64,52 & 34 & 56,67 \\
\hline 6. & Manula (65 tahun keatas) & 11 & 37,93 & 8 & 25,81 & 19 & 31,67 \\
\hline & inges & & - & 1 & 3,23 & 1 & 1,67 \\
\hline & Jumlah & 29 & 100 & 31 & 100 & 60 & 100 \\
\hline
\end{tabular}

Tabel. 2. Distribusi Frekuensi Jenis Kelamin Penderita Tuberkulosis Tahun 2011-2012 Di Puskesmas Harapan Raya Pekanbaru

\begin{tabular}{ccccccccc}
\hline & & & $\mathbf{2 0 1 1}$ & & $\mathbf{2 0 1 2}$ & \multicolumn{2}{c}{ Total } \\
No & Jenis Kelamin & F & \% & f & \% & f & \% \\
\hline 1. & Laki-laki & 21 & 72,41 & 23 & 74,19 & 44 & 73,33 \\
2. & Perempuan & 8 & 27,59 & 8 & 25,81 & 16 & 26,67 \\
& Jumlah & 29 & 100 & 31 & 100 & 60 & 100 \\
\hline
\end{tabular}

Tabel. 3. Distribusi Frekuensi Hasil Pemeriksaan BTA Penderita Tuberkulosis Tahun 2011-2012 Di Puskesmas Harapan Raya

\begin{tabular}{|c|c|c|c|c|c|c|c|}
\hline \multirow{2}{*}{ No } & \multirow{2}{*}{ Hasil Pemeriksaan BTA } & \multicolumn{2}{|c|}{2011} & \multicolumn{2}{|c|}{2012} & \multicolumn{2}{|c|}{ Total } \\
\hline & & $\mathbf{f}$ & $\%$ & $\mathbf{f}$ & $\%$ & $\mathbf{f}$ & $\%$ \\
\hline 1. & Positif 1+ & 4 & 13,79 & 5 & 16,13 & 9 & 15 \\
\hline 2. & Positif 2+ & 2 & 6,90 & 4 & 12,90 & 6 & 10 \\
\hline 3. & Positif 3+ & 11 & 37,93 & 11 & 35,48 & 22 & 36,67 \\
\hline 4. & Negatif & 10 & 34,48 & 5 & 16,13 & 15 & 25 \\
\hline 5. & Tanpa Keterangan & - & - & 4 & 12,90 & 4 & 6,67 \\
\hline 6. & TBC Kelenjar & 2 & 6,90 & - & - & 2 & 3,33 \\
\hline 7. & 1-9 Lapang Pandang & - & - & 2 & 6,45 & 2 & 3,33 \\
\hline & Jumlah & 29 & 100 & 31 & 100 & 60 & 100 \\
\hline
\end{tabular}

Berdasarkan hasil penelitian yang telah dilakukan pada tanggal 27 Juli s/d 01 Agustus 2013 bertempat di Ruang Medical Record (MR)
Di Puskesmas Harapan Raya Pekanbaru yang berjudul "Karakteristik Penderita Tuberkulosis 
Di Puskesmas Harapan Raya Tahun 2011-2012 Pekanbaru" adalah sebagai berikut:

Pembahasan pertama membahas karakteristik berdasarkan usia, dimana penderita Tuberkulosis dalam penelitian ini adalah mayoritas berada pada usia dewasa (21-45) tahun, yang ditunjukkan bahwa pada tahun 2011 sebanyak 14 orang $(48,28 \%)$ dan pada tahun 2012 sebanyak 20 orang $(64,52 \%)$. Disini peneliti menemukan terjadi peningkatan dari tahun 20112012.

Hal di atas sesuai dengan hasil penelitian Firdaus, dkk (2005), dengan judul "Faktor-Faktor Yang Berhubungan Dengan Kesembuhan Penderita TB Paru Di Poli Paru Rumah Sakit Persahabatan Jakarta Februari - Desember 2005". Hasil penelitian karakteristik penderita Tb di RS Persahabatan di Poli Paru mayoritas usia produktif atau usia dewasa sebanyak 80 0rang $(90,91 \%)$.

Menurut asumsi peneliti, usia produktif dapat mempengaruhi terjadinya penyakit TBC, karena orang yang berusia produktif biasanya akan bekerja dan melakukan aktivitas di luar rumah. Sehingga mudah terpapar dengan sumber polusi. Selain itu dengan aktivitas yang tinggi dan kurang istirahat dapat menyebabkan penurunan sistim imun, sehingga rentan terjadinya infeksi termasuk infeksi tuberkulosis. Hal ini sesuai dengan pendapat Achmadi (2005), dan Laban Yoannes (2008), bahwa di Indonesia 75 persen penderita TB Paru adalah kelompok usia tenaga kerja produktif.

Pembahasan kedua membahas karakteristik berdasarkan jenis kelamin. Peneliti menemukan bahwa kecenderungan penderita Tuberkulosis pada jenis kelamin laki-laki, yang ditunjukkan pada tahun 2011 sebanyak 21 orang $(72,41 \%)$ dan pada tahun 2012 sebanyak 23 orang $(74,19 \%)$.

Menurut hasil penelitian Firdaus, dkk (2005), dengan judul "Faktor-Faktor Yang Berhubungan Dengan Kesembuhan Penderita TB Paru Di Poli Paru Rumah Sakit Persahabatan Jakarta Februari - Desember 2005". Hasil penelitian karakteristik penderita Tb di RS Persahabatan di Poli Paru berdasarkan jenis kelamin mayoritas laki-laki sebanyak 53 orang $(60,23 \%)$.
Asumsi peneliti bahwa jenis kelamin dapat mempengaruhi untuk terjadinya penyakit TBC, karena laki-laki suka mengkonsumsi rokok dan pekerjaan yang mudah terpapar dengan sumber polusi. Hal ini sesuai dengan pendapat Achmadi (2005), bahwa laki-laki mudah terkena penyakit TB Paru karena pola gaya hidupnya yang tidak sehat. Seperti, mempunyai kebiasaan merokok, kurangnya olah raga dan istirahat yang cukup sehingga memudahkan terjangkitnya TB paru.

Pembahasan ketiga membahas karakteristik berdasarkan pemeriksaan BTA yang menunjukkan bahwa karakteristik Penderita Tuberkulosis dalam penelitian ini mayoritas BTA positif $3+$, yang ditunjukkan bahwa pada tahun 2011 sebanyak 11 orang $(37,93 \%)$ dan pada tahun 2012 sebanyak 11 orang $(35,48 \%)$.

Menurut Ditjen PP \& PL Kementerian Kesehatan RI (2011), pemeriksaan dahak mikroskopik merupakan salah satu strategi untuk mengidentifikasi penyakit TBC, agar dapat dilakukan penatalaksanaan yang tepat sesuai dengan hasil pemeriksaan tersebut. Jika hasil pemeriksaan diperoleh hasil positif, baik positif 1, positif 2 dan positif 3 , maka penderita TBC dianggap sebagai penderita TBC aktif. Dengan demikian penderita TBC tersebut dikhawatirkan akan menularkan penyakit kepada orang lain, terutama kepada anggota keluarga. Sebagai langkah pengobatan pada tahap ini, maka penderita diberikan pengobatan pada tahap intensif secara tepat, sehingga biasanya penderita menular menjadi tidak menular dalam kurun waktu 2 minggu.

Selain itu, berdasarkan data proporsi pasien TB Paru BTA positif diantara suspek yang diperiksa dahak tahun 2005-2011 masih dalam range target yang diharapkan (5-15\%). Sesuai dengan target tersebut, angka proporsi pasien TB Paru BTA positif diantara suspek yang diperiksa ini sekitar 5-15\%. Apabila angka ini bila terlalu kecil $(<5 \%)$ kemungkinan disebabkan antara lain penjaringan suspek terlalu longgar, banyak orang yang tidak memenuhi kriteria suspek, atau ada masalah dalam pemeriksaan laboratorium (negatif palsu). Sedangkan bila angka ini terlalu besar (>15\%) kemungkinan disebabkan antara 
lain penjaringan terlalu ketat atau ada masalah dalam pemeriksaan laboratorium (positif palsu).

Sesuai dengan data di atas peneliti berpendapat bahwa hasil pemeriksaan dahak sangat diperlukan, karena dengan hasil pemeriksaan tersebut penderita TBC akan memperoleh pengobatan secara tepat, dan jika setelah dilakukan pengobatan penderita tidak mengalami perubahan, maka sebagai seorang perawat harus melakukan evaluasi apa yang menjadi penyebab ketidaksembuhan pasien. Dengan demikian pendidikan kesehatan sangat perlu dilakukan oleh perawat kepada penderita TBC yang sedang menjalani pengobatan.

Selain hal di atas, ada beberapa hal yang ingin peneliti bahas, diantaranya adalah tentang data pekerjaan dan status sosial ekonomi. Pada awal penelitian, peneliti merencanakan akan mengumpulkan data tentang pekerjaan dan status sosial ekonomi penderita responden.

Karena menurut peneliti pekerjaan dan status ekonomi sangat mempengaruhi karakteristik penderita TBC. Sesuai dengan teori yang peneliti peroleh Jenis pekerjaan menentukan faktor risiko apa yang harus dihadapi setiap individu. Bila pekerja bekerja di lingkungan yang berdebu, paparan partikel debu di daerah terpapar akan mempengaruhi terjadinya gangguan pada saluran pernafasan. Paparan kronis udara yang tercemar dapat meningkatkan morbiditas, terutama terjadinya gejala penyakit saluran pernafasan dan umumnya TB Paru. Sedangkan menurut WHO tahun 2007 menyebutkan 90 persen penderita TB di dunia menyerang kelompok sosial ekonomi lemah atau miskin dan menurut Enarson TB merupakan penyakit terbanyak yang menyerang negara dengan penduduk berpenghasilan rendah.

Dengan demikian peneliti berharap adanya penambahan data pendokumentasian pada data register penderita $\mathrm{TBC}$, karena data tersebut juga dapat dijadikan sebagai acuan evaluasi tingkat keberhasilan pengobatan penderita TBC, sehingga angka penyakit TBC menjadi menurun dan masyarakat tumbuh sehat sejahtera sesuai dengan visi kesehatan Indonesia 2014.

\section{DAFTAR PUSTAKA}

Achmadi. (2005). Karakteristik Penderita Penyakit TBC. http://karakteristik penderitaTbc.com. Diperoleh pada tanggal 26 Oktober 2013

Admin. (2012). Penyakit TBC. http://macammacampenyakit.com.

Diperoleh pada tanggal 26 Oktober 2012

Asih Niluh Gede Yasmin \& Effendi Christanty. (2003). Keperawatan Medikal Bedah:

Dengan Klien Gangguan Sistem Pernapasan. Jakarta: EGC

----. (2012). Pengertian Pekerjaan. http://id.wikipedia.org. Diperoleh pada tanggal 27 Oktober 2012

Departemen Pendidikan dan Kebudayaan. (2002). Kamus Besar Bahasa Indonesia (edisi kedua). Jakarta: Balai Pustaka. http://books.google.co.id. Diperoleh pada tanggal 11 Februari 2013

Ditjen PPL\&PL Kementerian Kesehatan RI. (2011). Laporan Situasi Terkini Perkembangan Tuberkulosis Di Indonesia Januari-Juni 2011. http://www.tbindonesia.or.id/pdf/2011/Ind onesiaReport2011.pdf. Diperoleh pada tanggal 27 Oktober 2012

Effendi. (2012). Penanganan Paripurna, Solusi Penanggulangan $T B$. http://hariansinggalang.co.id. Diperoleh pada tanggal 30 November 2012

Faud Aried. (2011). Pemeriksaan Sputum. http://ariedfaud.blogspot.com/2011/10/pe meriksaan-sputum.html. Diperoleh pada tanggal 26 Oktober 2012

Firdaus, dkk (2005). Faktor-faktor Yang Berhubungan Dengan Kesembuhan

Penderita TB Paru di Poli Paru Rumah Sakit Persahabat Jakarta Februari - Desember 2005. Media litbang kesehatan XVI Nomor 4 tahun 2006. Diperoleh pada tanggal 26 Agustus 2013

Gilarso T. (2004). Pengantar Ilmu Ekonomi Makro. Kanisius (Anggota IKAPI) http://books.google.co.id. Diperoleh pada tanggal $11 \quad$ Februari 2013

Hasan. (2004). Analisa Data Penelitian Statistik. Jakarta: Bumi Aksara 
Hasugion Fredo. (2010). Karakteristik Pasien HIV dengan Tuberkulosis di RSUP HAM, Medan tahun 2008 - 2010. http://repository.usu.ac.id. Diperoleh pada tanggal 26 Agustus 2013

Hidayat, A. (2007). Riset Keperawatan dan Teknik Penulisan Ilmiah. Jakarta: Salemba Medika

Hamidanah. (2010). Proposal Penelitian Pengaruh Kondisi Sosial Ekonomi Keluarga. http://www.scribd.com. Diperoleh pada tanggal 27 Oktober 2012

Hardiwinoto. (2011). Ilmu Kesehatan Masyarakat. http://ilmu-kesehatanmasyarakat.blogspot.com. Diperoleh pada tanggal 27 Oktober 2012

Ida Andini. (2007). Perbedaan Sikap Terhadap Seks Berdasarkan Jenis Kelamin. http://repositorigunadarma.ac.id.

Diperoleh pada tanggal 27 Oktober 2012

Laban Yoannes. (2008). Penyakit TBC dan cara pencegahannya. PT. Kanisius

Mansjoer Arif. (2000). Kapita Selekta Kedokteran Edisi Ketiga Jilid 2. Media Aesculapius

Mujiatun. (2009). Sistem Pernapasan Makhluk Hidup. PT. Aneka Ilmu

Manalu P Sahat Helper. (2010). Faktor-Faktor Yang Mempengaruhi Kejadian TB Paru Dan Upaya Penanggulangannya. http://ejournal.litbang.depkes.go.id.

Diperoleh pada tanggal 27 Januari 2013

Martina Devi Adinda. (2012). Hubungan Usia, Jenis Kelamin, Dan Status Nutrisi Dengan Kejadian Anemia Pada Pasien Tuberkulosis. http://ejournals1.undip.ac.id. Diperoleh pada tanggal 27 Januari 2013

Perhimpunan Dokter Paru Indonesia. (2006). Tuberkulosis Pedoman Diagnosis \&
Penatalaksanaan Di Indonesia. http://www.klikpdpi.com. Diperoleh pada tanggal 27 Januari 2013

Prabu. (2008). Klasifikasi dan Gejala TBC. http://putraprabu.wordpress.com.

Diperoleh pada tanggal 27 Oktober 2012

Prabu. (2008). Faktor Resiko TBC. http://putraprabu.wordpress.com.

Diperoleh pada tanggal 27 Oktober 2012

Richard. (2009). Karakteristik kepribadian. http://charlerichardin.blogspot.com Diperoleh pada tanggal 27 Oktober 2012

Rahardiyanti Widhi dkk. (2012). Gambaran Karakteristik Penderita Tuberkulosis Pada Anak Umur 1 - 5 Tahun Yang Berobat Di Balai Kesehatan Paru Masyarakat Kota Semarang.

http://www.ejournals1.undip.ac.id/index.p $\mathrm{hp} / \mathrm{jkm} /$. Diperoleh pada tanggal 27 Januari 2013

Setiowati Tetty, dkk. (2007). Biologi Interaktif Kelas XI IPA. Jakarta: Azka Press. http://books.google.co.id. Diperoleh pada tanggal 23 Februari 3013

Smeltzer C Suzanne dan Bare G Brenda. (2002). Keperawatan Medikal Bedah Vol 1. Jakarta:EGC

Soedarsono Soemarno. (2006). Membangun Kembali Jati Diri Bangsa._Penerbit: PT Elex Media Computindo. http://books.google.co.id. Diperoleh pada tanggal 11 Februari 2013

Sutrisno. (2005). Karakteristik PJK. http://google.com. Diperoleh pada tanggal 27 Oktober 2012

Wahyu Ginanjar Genis DR. (2008). Mencegah dan Menangkal TBC pada Anak. Dian Rakyat 